\title{
A Study of Clothing Industry Competitiveness with Porter's Five Force Approach in Kabupaten Agam Central Industry (A Preliminary Study of Ampek Angkek, Banuhampu, Sungai Puar)
}

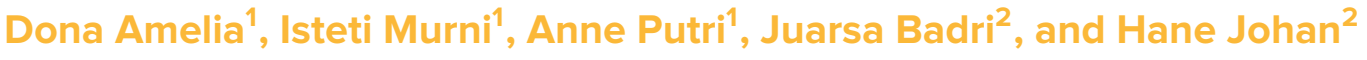 \\ ${ }^{1}$ Sekolah Tinggi Ilmu Ekonomi H.Agus Salim Bukittinggi \\ ${ }^{2}$ Sekolah Tinggi Ilmu Ekonomi El Hakim, Solok
}

\section{Abstract}

The purpose of the study is to explore the strength of competitiveness of apparel industry in Agam district. The competitiveness of typical SMEs is studied by taking into account the dimensions of newcomer threats, government support, supplier

Corresponding Author:

Dona Amelia

donarondy@gmail.com

Received: 18 January 2019

Accepted: 24 March 2019

Published: 31 March 2019

Publishing services provided by Knowledge E

(c) Dona Amelia et al. This article is distributed under the terms of the Creative Commons

Attribution License, which permits unrestricted use and redistribution provided that the original author and source are credited.

Selection and Peer-review under the responsibility of the First ELEHIC Conference Committee.

\section{G OPEN ACCESS} strength, buyers and the availability of substitute products by using Porter's Five Forces approach. The work is Descriptive Explanatory research. The research was conducted in the form of survey, interview.Despite the existing apparel industry, some problems still expose in Kabupaten Agam garment industry. There is a trend showing that the garment industry is replaced by retail garment store in these two decades. Since the year 2000, Kabupaten Agam's garment industry has been facing both domestic and external difficulties, such as lack of labor supply, the financial crisis, the global economic downturn, imported garment and the rising labor costs, raw material prices.

Keywords: Competitiveness, Porter's Five Force, Clothing Industry

\section{Introduction}

National Textile Industry and Textile Product is a strategic industry which play pivotal role in supplying clothes need, labor absorption, and nonfuel foreign exchange contributor. Though the raw material, cotton fiber, is still dominated on an import basis, its contribution to the growth of processing industry is highly significant. It leads government to have concern of assuring the existence of textile industry and textile product runs smoothly and develop sustainably [1].

The growth equation of textile industry and textile product in Jawa has been conforming the negative coefficient of total factor productivity which explaining there was 
no technological advancement. The cause of no technological advancement is the displacement foreign investor to abroad and the labor intensive nature of local industry. The displacement of foreign investor to abroad not only causing the movement of physical resource but also the movement of technology movement. In addition, the local industry of textile industry and textile product in Jawa is struggling with low quality of labor force [2].

Agam as one of the region that has high local income in West Sumatra Province, Indonesia currently approaches SME as the main economic activities. The 2016 Data indicated that the number of SME in Agam was around 14.203 units where 11.869 of them were classified as micro business, 2.222 small business and the rest 85 were medium business [3].

Research by Yomalinda [4] explained that industrial sub sectors in Agam were distinguished and competitive; which resulting their products potential to be expanded to leverage the local economic income. Yomalinda's research also indicating that the creative industries of traditional embroideries in Agam are part of the local commodities which are able to compete with other industrial sub sectors that consist of both local and religious values.

Despite the garment industries are regarded as the main local commodities, they are inseparable from problems. Since 2000 the garment industries in Agam region has been showing regeneration problems. Previously, the business was inherited to the family members including children and grandchildren but the current situation is showing the opposite trend. As the parents no longer urge their children to continue the family business, instead they encourage their children to work as white collar workers.

Problems also comes from the limitation of labor who are willing to work in garment industries. The lack of labor in garment industries have been occurring since 2000 as the number of people who have interest to the field of work was gradually declining. Contradictive to the previous years, there were labors who are willing to work as cloth cutter, sewer, and cloth packing are plentiful. The workers came from other region outside Agam including Solok, Lima Puluh Kota, Tanah Datar and others. Since the local autonomy has been making these regions to develop their own garment industries as the potential SME, it results the number of garment labor in Agam region is also affected by this approach.

Besides, most of the garments industry owners has changed their business strategy from making their own product to become a retail seller. They decided to become retail sellers because the retailing process business is more simple and easier than making their own garment industry. As a retail seller, they only need to buy the product from 
wholesaler from Tanah Abang which then be sold in retail at Pasar Aur Kuning, Bukittinggi.

Other factors that threaten the garment industries in Agam region is the availability of imported products from China which are cheaper compare to the garment products produced by local businessmen in Agam. As the result, most of the garment industry owners decided to close their enterprises and create a new business in retail. Even though some of the local garment industries in Agam are still continuing their business but their number is small.

\section{Theoretical Background}

Study of competitiveness in the case of the U.S. apparel industry found a causal effect of industry's performance in productivity, measured by total factor productivity growth, on competitiveness of the industry, measured by income growth. The causal relationship between productivity and competitiveness was not confirmed for the three other industries in the study: U.S. textile industry and Japanese textile and apparel industries. No previous study has examined longitudinal effect of trade and productivity in the textile and apparel industries on the industries' competitiveness [5].

The competitiveness rivalry among countries related to governmental mandate in labor costs in Thailand. The study provide a window into Thailand's government institution to embrace research and development to raise the international image and competitiveness of its apparel products. Additionally, leadership and workforce teamwork are key components which affect the industry future success [6]

Discussion within the Porter's "Diamond Model", showing that Guangdong's textile product still has advantages in comparatively low cost labor force, complete chain of textile and garment industry and lots of specialized industrial clusters. But with the increase of costs, shortage of land and labor, lack of own brands and domestic demand, low profit rate and strong rivals, Guangdong's garment industrial competitiveness seems to became weakened. As the amount of export could reflect the competitiveness in a way, four regressions are generated to detect the factors affecting the export [7].

The study in Ethiopia finds that the composite of the five independent variables of factor conditions: demand conditions; related and supporting industries; industry's strategy, structure and rivalry; role of government; and chance factors and dependent variable are accounted for 73 percent variance for the competitiveness of garment industry in Ethiopia. The independent variables show the positive effect on predicting the dependent variable (except the demand conditions). Factor conditions and chance factors were 
found to be statically significant determinants for the competitiveness of the garment industry in Ethiopia [8].

Turkish textile and clothing producers have been quite successful in enhancing their competitive position in major markets, namely, in the EU and the US, and seem to be in a strong position for the coming decade. However, major changes in the textile and clothing markets most importantly is the elimination of quotas in developed countries after January 1, 2005, would transform the competitive conditions in these markets. The Turkish textile and clothing industries that earn about $40 \%$ of export revenue should prepare themselves against these changes in order to protect the existing shares in major markets [9].

Porter's Five Forces Framework is a tool for analyzing competition of a business. It is used to determine the competitive intensity and, therefore, the attractiveness of an industry in terms of its profitability [10]. An "unattractive" industry is one in which the effect of these five forces reduces overall profitability. The five-forces perspective is associated with its originator, Michael E. Porter of Harvard University. This framework was first published in Harvard Business Review in 1979.

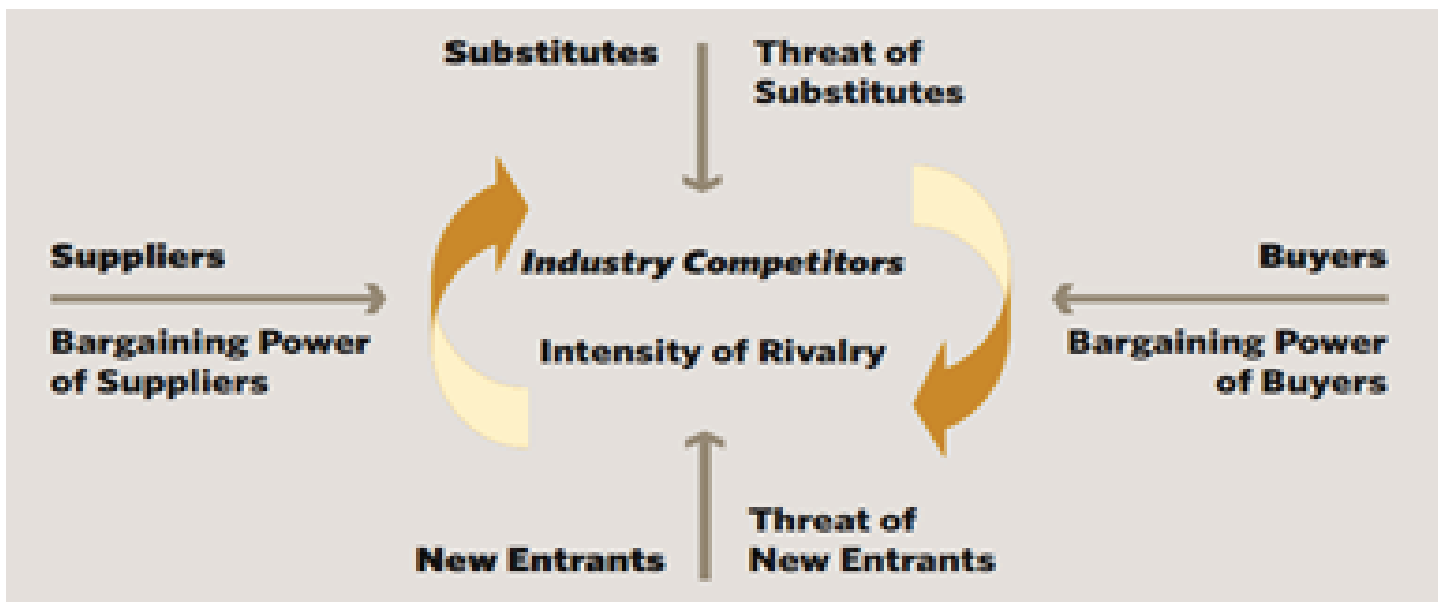

Figure 1: PORTER'S FIVE FORCES MODEL.

\subsection{Threat of new entrants}

This force will determine how ease/difficult to enter a particular industry. If an industry could gain high profitability with little obstacle, the competitor will soon raise. The more competitor compete in the same market, the less profitability will the industry gain. Conversely, the higher obstacle to new entrant, the better the company's position in profit area. Some obstacle faced by new entrants are: capital intensiveness, high technology, patent/trademark, economies of scale, customer loyalty, government regulation. 


\subsubsection{Threat of substitutes}

This constraint or threat arises when the customer/buyer is obtaining cheaper substitute product or better product substitute with lower diversion cost. The less product substitute available in the market, the more profitable the company will be.

\subsection{Bargaining power of customers}

This force quantify bargaining power of buyer/customer. The higher bargaining power of buyer demanding lower prices or better product quality, the less profit will be obtained by producer company. Lower product price means lower income for the company. On one side, the company requires high financial resource to produce better product quality. On the other side, the less buyer's bargaining power the more profitable it will be for the company. Buyer's bargaining power is high when the number of substitute product is abundant, more available product stock with less buyer.

\subsection{Bargaining power of suppliers}

Strong bargaining power of supplier enable supplier to sell raw material at excessive price or sell low quality raw material to buyer. Then, company's profit will be lower because it needs high cost to obtain good quality raw material. Conversely, the lower supplier's bargaining power, the higher profit for the company. The supplier's bargaining power becomes higher if limited supplier available to supply particular raw material whilst more buyer want to acquire it, only limited substitute raw material available or the supplier monopolize the existence raw material.

\subsection{Industry rivalry}

This force is the main determinant, the company has to compete aggressively to gain bigger market share. The company will be benefited if company's position is strong and the competition level in the same market is low. The tighter competition will take place if there are more rivalry capturing the same market share, low customer loyalty, the product is freely replaceable and most competitor have equal capability in detain the competition. 


\section{Methodology}

This research is descriptive explanatory research which is conducted to describe a certain situation or population that is factual in a systematic and accurate and will usually answer concerned with competitiveness apparel industry in Agam district. It uses qualitative approach. Survey by using questionnaires using five-point Interval scale. The population in this study is the apparel industry in Agam District, the sample is selected by stratified random sampling in three district: kecamatan ampek angkek, kecamatan banuhampu dan kecamatan sungai pua.

Descriptive statistics is used to visualize data especially if there was a lot of it. Descriptive statistics is considered able to present the data in a more meaningful way, which allows simpler interpretation of the this preliminary study of competitiveness of garment industry in KabupatenAgam.There are two general types of statistic that are used to describe data:

1. Measures of central tendency: these are ways of describing the central position of a frequency distribution for a group of data. The central position is described using a number of statistics, including the mode, median, and mean.

2. Measures of spread: these are ways of summarizing a group of data by describing how spread out the scores are. To describe this spread, a number of statistics are available to us, including, absolute deviation, variance and standard deviation.

TABLE 1

Table I. Criteria to Scale Mean Score

\begin{tabular}{ll}
\hline Range & Degree \\
\hline $1.25-1.99$ & Most unfavourable \\
$2.00-2.74$ & Unfavourable \\
$2.75-3.49$ & Average \\
$3.50-4.24$ & Favourable \\
$4.25-5.00$ & Most favourable \\
\hline
\end{tabular}

\section{Results}


TABLE 2: Descriptive Analysis of Respondents.

\begin{tabular}{|c|c|c|}
\hline Sex & Respondent & Percentage \\
\hline Male & 37 & $40.9 \%$ \\
\hline Female & 39 & $54.1 \%$ \\
\hline Age & Respondent & Percentage \\
\hline$<30$ years & 14 & $21.2 \%$ \\
\hline $31-40$ years & 23 & $34.8 \%$ \\
\hline $41-50$ years & 19 & $28.8 \%$ \\
\hline $51-60$ years & 9 & $13.6 \%$ \\
\hline$>61$ years & 1 & $1.5 \%$ \\
\hline Education Background & Respondent & Percentage \\
\hline Elementary School & 4 & $6.1 \%$ \\
\hline Junior High & 11 & $16.7 \%$ \\
\hline Senior High & 37 & $56.1 \%$ \\
\hline University Graduate & 14 & $21.2 \%$ \\
\hline Number of Worker & Respondent & Percentage \\
\hline$<5$ people & 38 & $57.6 \%$ \\
\hline 5-10 people & 21 & $31.8 \%$ \\
\hline 10-15 people & 5 & $7.6 \%$ \\
\hline 15-20 people & 1 & $1.5 \%$ \\
\hline$>20$ people & 1 & $1.5 \%$ \\
\hline $\begin{array}{l}\text { Worker Education } \\
\text { Background }\end{array}$ & Respondent & Percentage \\
\hline Elementary School & 8 & $12.1 \%$ \\
\hline Junior High & 30 & $45.5 \%$ \\
\hline Senior High & 28 & $42.4 \%$ \\
\hline
\end{tabular}

\subsection{Descriptive analysis of respondents}

The survey toward 66 garment businessmen in Agam indicate an equal number between male and female business owners. It showed that $54,1 \%$ or garment industry owners is female while the rest $40,9 \%$ is male. The fact is, the garment industries in Agam region is managed by husband and wife where each of them share different role. The husbands have the main role in production while the wife focus on marketing and selling.

Most of the business owners in Agam's Garment industries are still in their productive age, $34,8 \%$ of them are around 31 to 40 years, and only $28,8 \%$ of them who are 41 to 
50 years old. The production is conducted in their own house, so they can regulate and manage the working time flexibly. The business owners who are up to 40 years old often delegate some of the works to other family members of to their trusted workers.

The education background of the garment industry business owners is dominated by high school graduates from about $56,1 \%$, only $6,1 \%$ of them who graduated from Elementary School. followed by Senior High School graduate, most of the business owners are also complete their university studies, as 21,2 of them is university graduate. It indirectly implies that educations is important to the business owners in Agam region.

The survey shows that most of the business owners has more than 5 workers, those who only have 5 workers are actually those who just start their own business. Only 1,5\% of them who have workers more than 20 people, so it means that their enterprise is quite stable.

The survey indicates that the workers on garment industries in Agam is mostly Junior high Graduate for around $45,5 \%$. While those who only complete Elementary School is only around $12,1 \%$.

\subsection{Business performance description of apparel industry in Kabu- patenAgam}

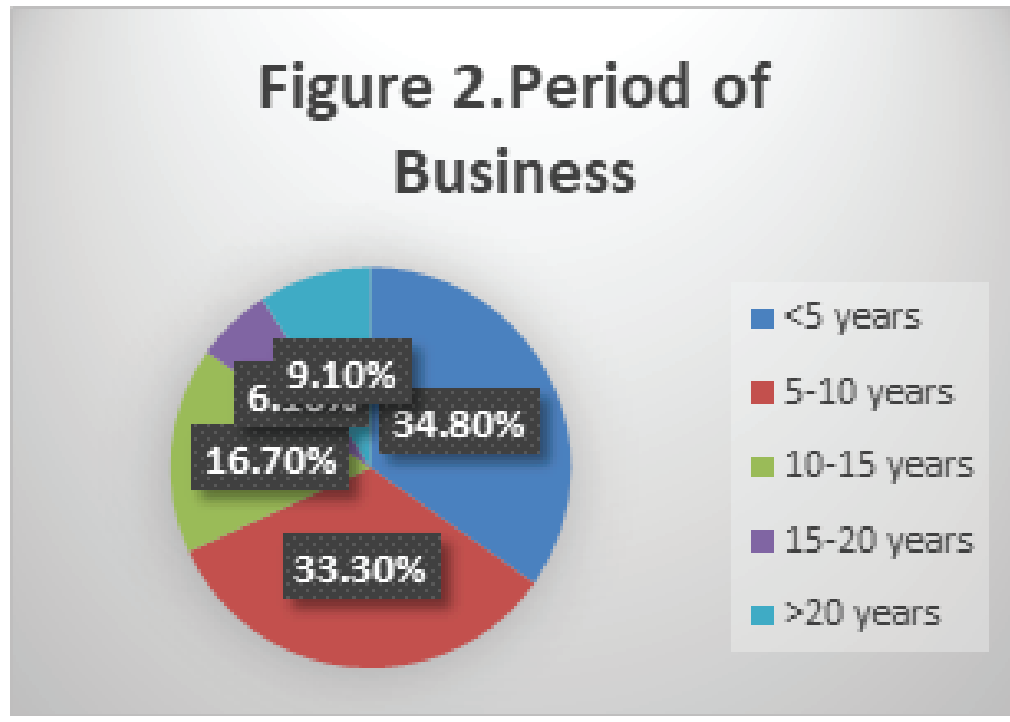

Figure 2: Source: Primary Data.

The diagram shows the business period of garment industries in Agam region, as $33,30 \%$ of them has been operated for 5 to 10 years. However, only $9,10 \%$ of them that has been operated for more than 20 years. 


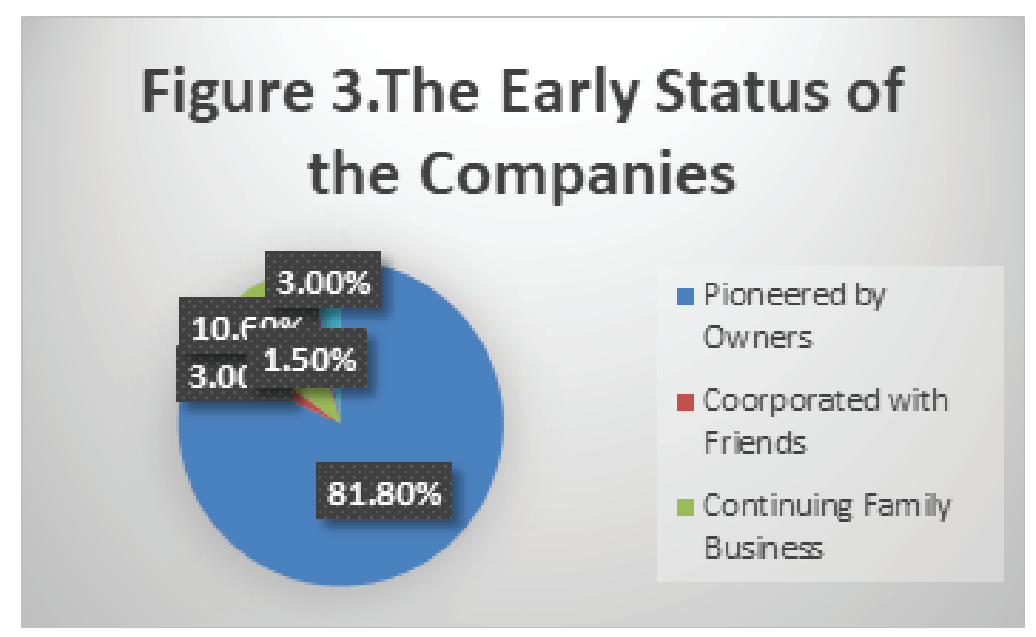

Figure 3: Source: Primary Data.

The diagram describes the early status of the garment business industries in Agam region, as most of the owners around $81,80 \%$ are actually pioneered the business. While the least case is garment industry which is originally continuing their friend business for around $1,50 \%$.

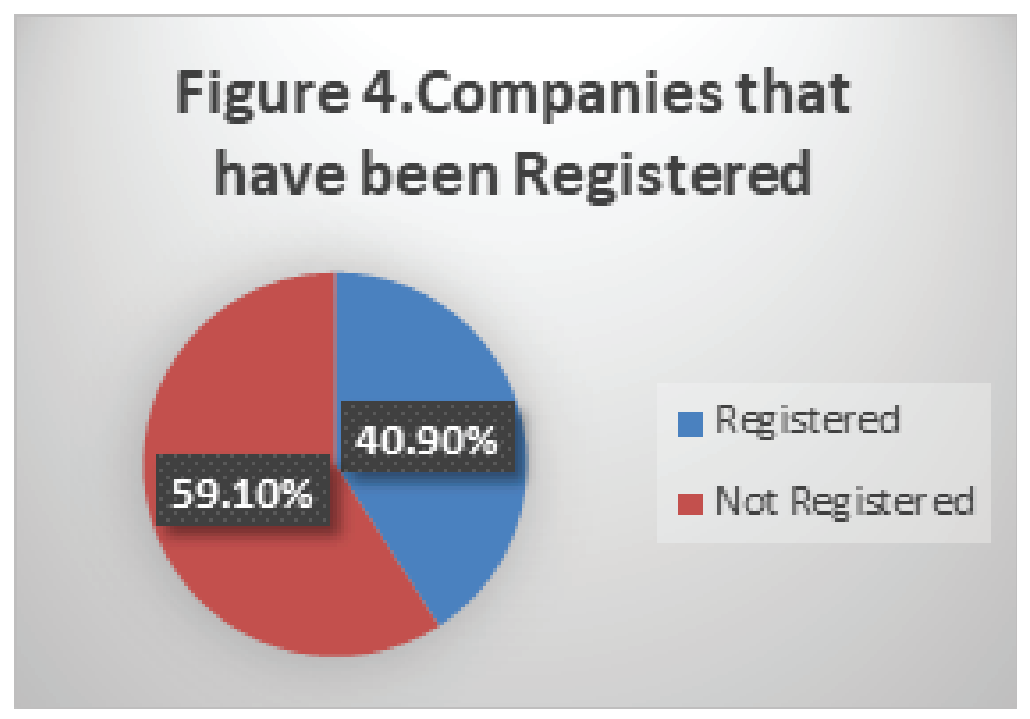

Figure 4: Source: Primary Data.

The diagram indicates that most of the garment business in Agam has been registered, as it shows that $59,10 \%$ owners has legalized their business. While the rest $40,90 \%$ has not yet registered their business, it may occur because the business owners want to produce product only and they believe that registering their business won't be necessary.

The source capital of the garment industry in Agam region is mostly come from their private money and saving, as $75,80 \%$ of the owners finance their own business; $1,50 \%$ of them collect capital from others including pawnshop, moneylender, non formal financial 


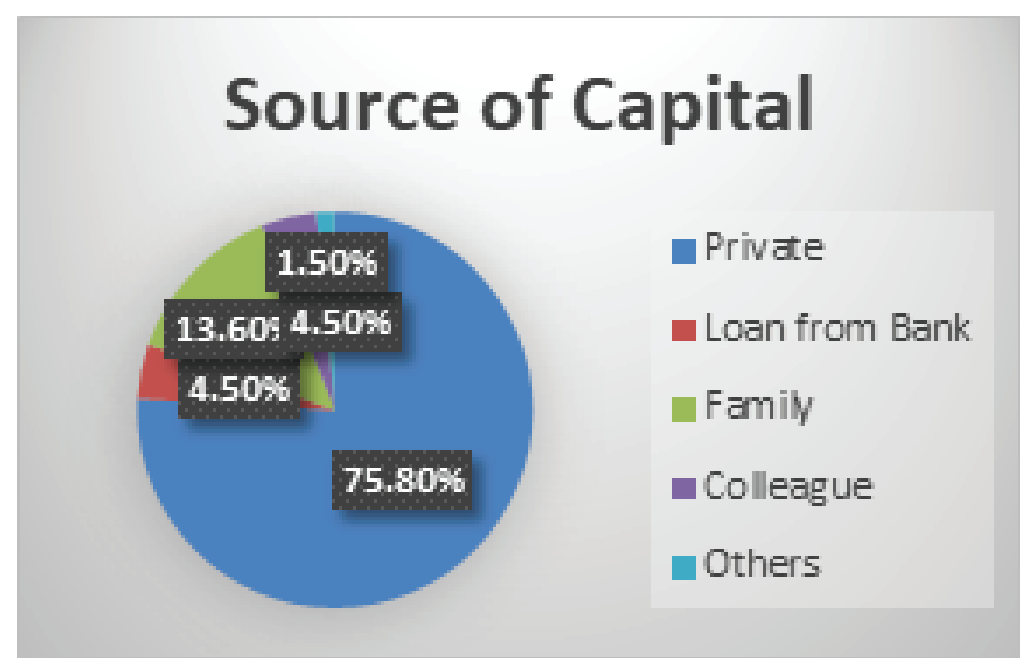

Figure 5: Source: Primary Data.

assistant such as PKK, religious group, and others. Some of the capital are originally taken from partnership, non Bank institution such as union, and micro finance institution.

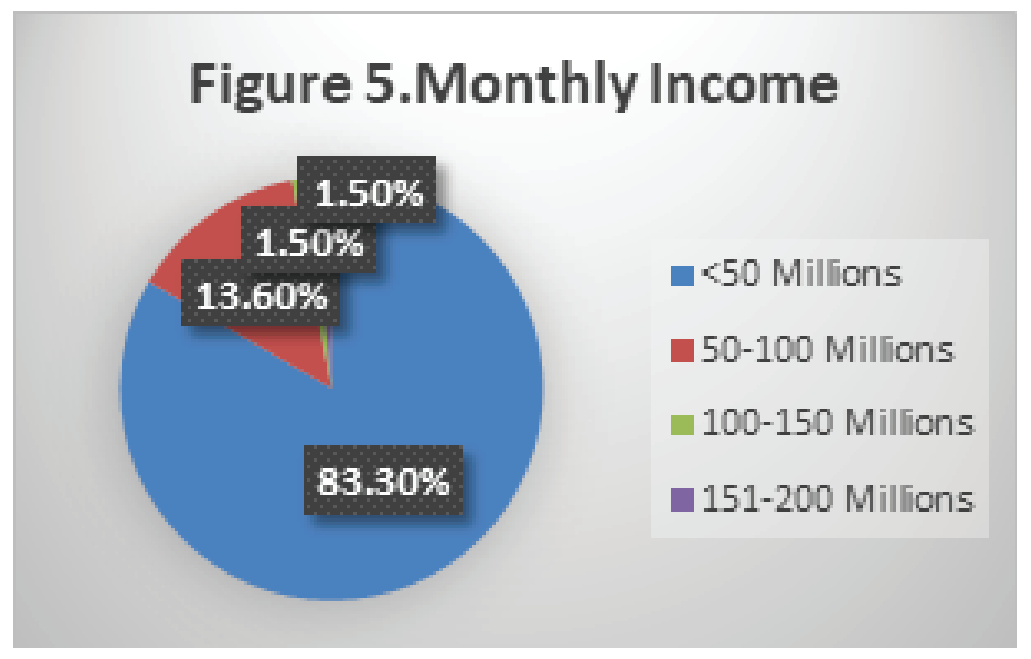

Figure 6: source: Primary Data.

The monthly income of the garment industries in Agam region which is less than 50 millions is around $83,30 \%$. While business owners who able to collect benefit around 150 to 200 millions is only around 1,50\%; this business owns usually has a stable enterprise that makes them able to collect at least 150 millions in a month.

The diagram indicates that 84,80 business owners in Agam did not get any training and coaching from the local government, so they learn how to run the business base on experience. Only $15,20 \%$ get training and coaching from the local government. 


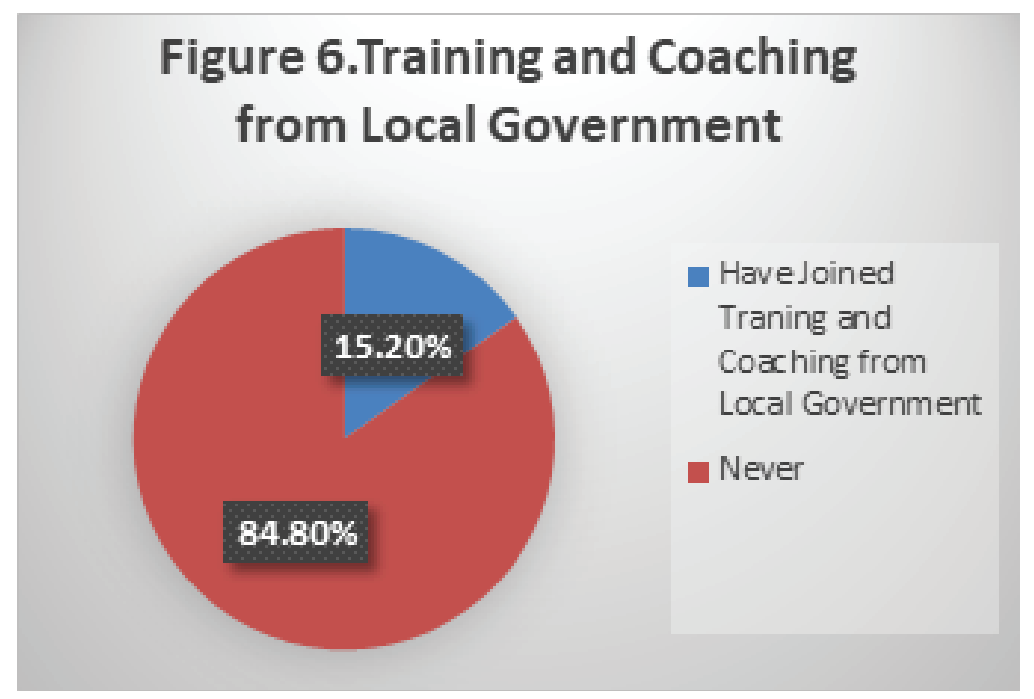

Figure 7: Source: Primary Data.

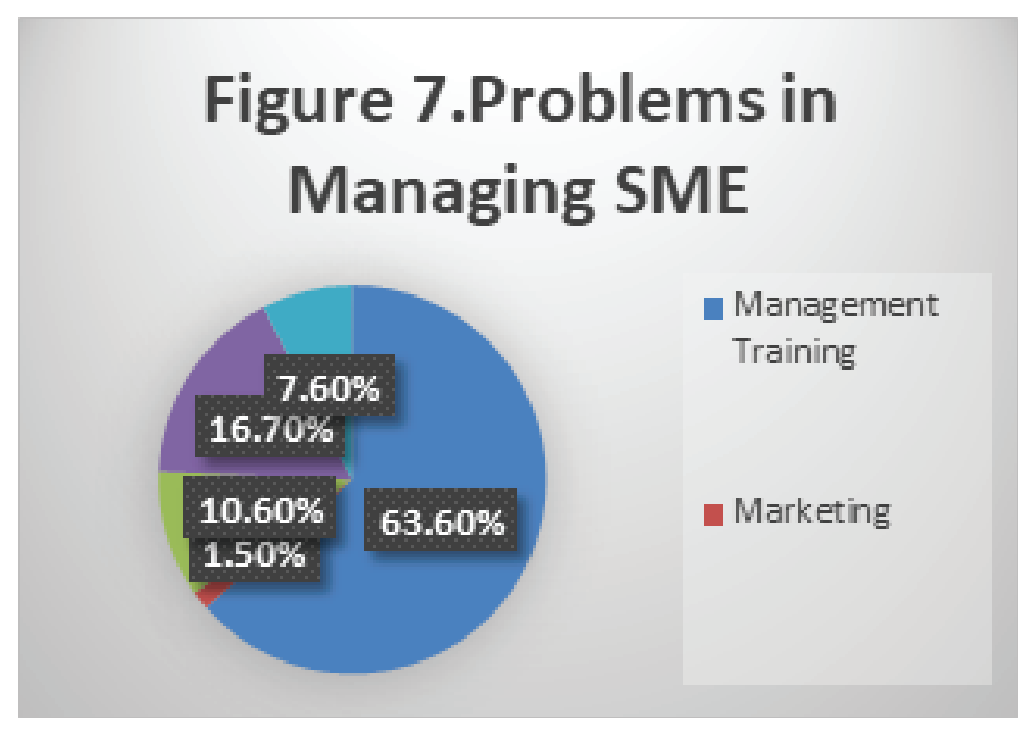

Figure 8: Source: Primary Data.

The limited support which is given by the local government toward business owners make them rely on their own experience. As the result, most of them experience problems in marketing $(1,50 \%)$, but the most dominant problem which is faced by the business owners is Management training (63,60\%).

Business owners who start their business from zero stated that the local government has support them trough their early stage, as $74,20 \%$ of them stated that the government support toward their business is considered good. While the rest 25,80 considered the local government support as low. Business Owners who are supported by the government are usually those who already familiar with the local government officers and programs, and those who already have their own brand. 


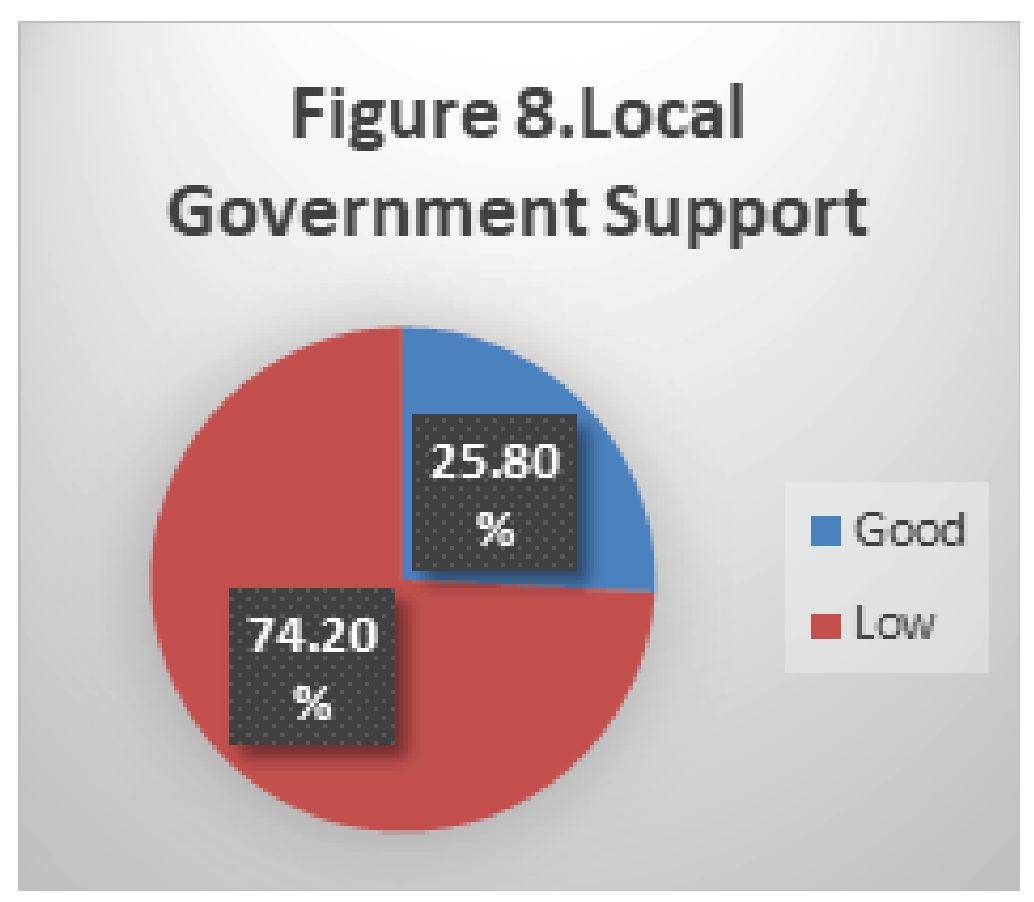

Figure 9: Source: Primary Data.

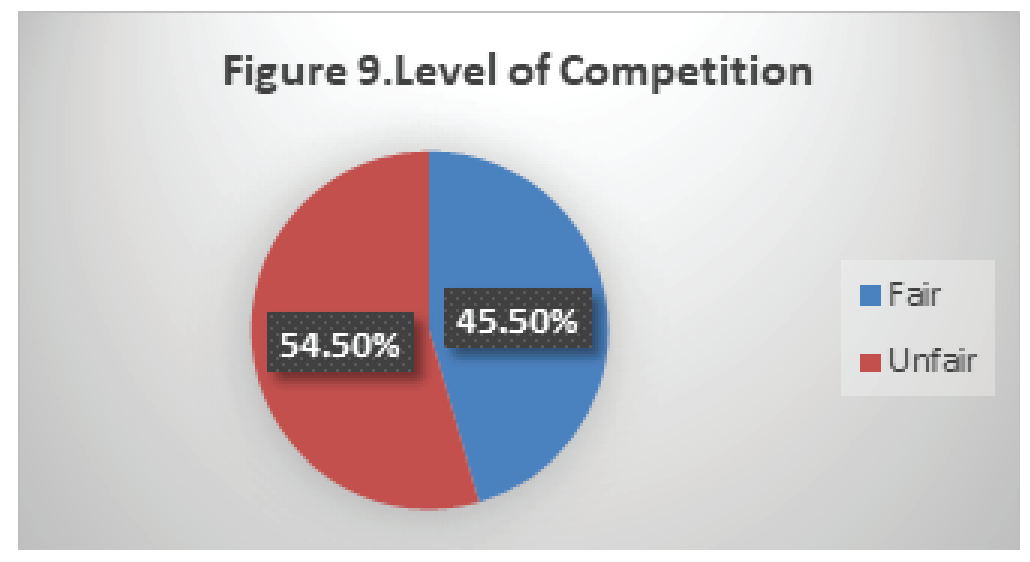

Figure 10: Source: Primary Data.

At the end, the poor support from the government cause unfair competition among business owners, as it shows percentage $54,50 \%$.

As the result of unfair competitiveness among business owners, only $68,20 \%$ of them who have access to the market.

The role of ASEAN Free Market toward the local garment business in Agam has not been confirmed, as it surveyed around $68,20 \%$. 


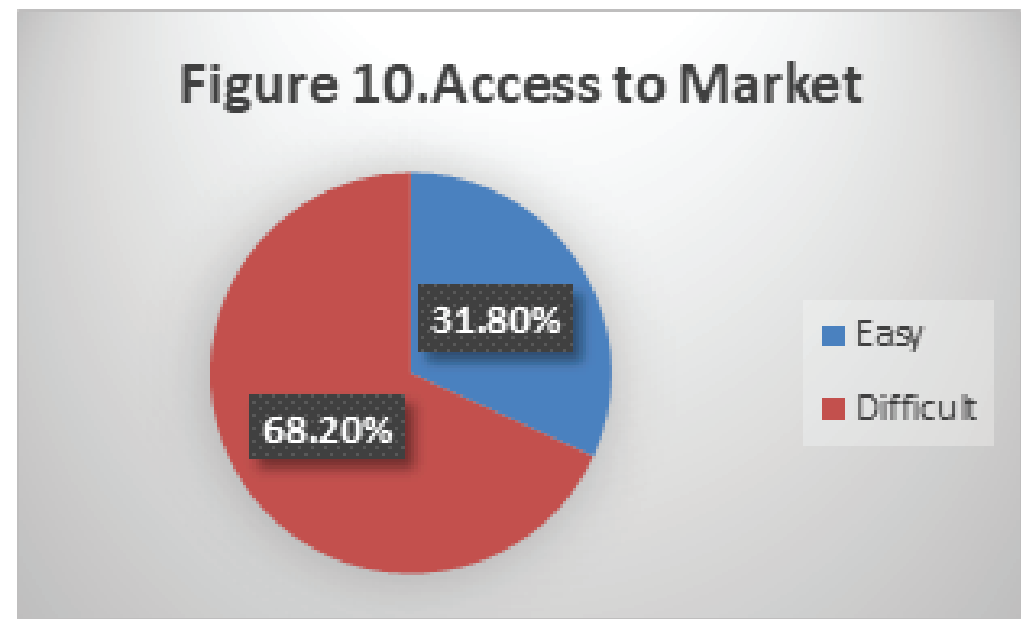

Figure 11: Source: Primary Data.

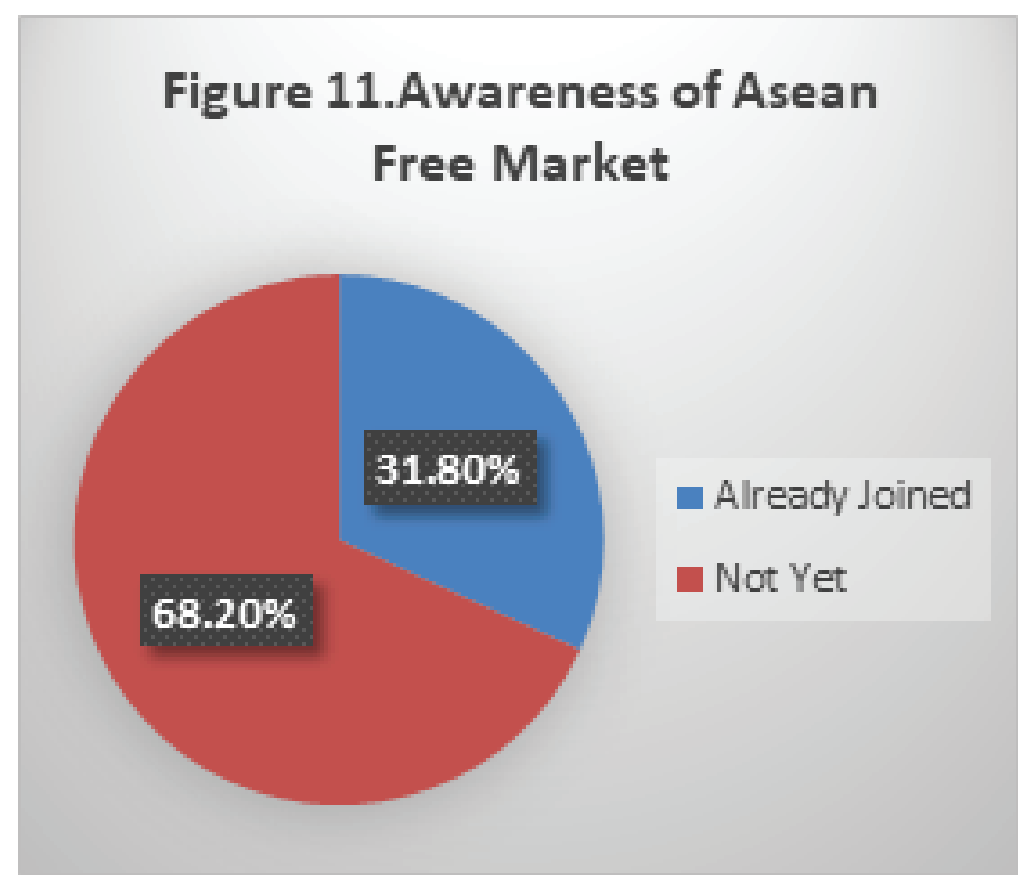

Figure 12: Source: Primary Data.

\subsection{Description of competitiveness of apparel industry in Kabu- patenAgam}

The business owner's perspective toward the rise of new business in garment industries may directly affect the owners, even if the new business from the local community are concerned in Java Island and overseas. The digital era that are now making internet access and online shopping popular also threaten the garment business owners in Agam region.

Supplier has a vital role in garment business, so both supliers and business owners agree that they need to maintain good relationship among them. When unexpected case 
TABLE 3: Description of Competitiveness Forces: Thread from New Business.

\begin{tabular}{|c|c|c|c|c|}
\hline No & Competitiveness & $\begin{array}{c}\text { Interval Scale } \\
\text { Strongly Strongly } \\
\text { Disagree Agree 1-5 }\end{array}$ & $\begin{array}{l}\text { Std.Error of } \\
\text { Mean }\end{array}$ & $\begin{array}{c}\text { Std. } \\
\text { Deviation }\end{array}$ \\
\hline \multirow[t]{3}{*}{ I } & $\begin{array}{l}\text { Thread from New Business } \\
\text { a. The arise of new garment } \\
\text { business who from the local } \\
\text { community that become a } \\
\text { competitor toward my own garment } \\
\text { business (example: Tasikmalaya, } \\
\text { Jakarta,Bandung and others) }\end{array}$ & $\begin{array}{l}\mathbf{2 , 2 7 2} \\
2,515\end{array}$ & $\begin{array}{l}\mathbf{0 , 1 6 3} \\
0,206\end{array}$ & $\begin{array}{l}1,330 \\
1,675\end{array}$ \\
\hline & $\begin{array}{l}\text { b. the arise of new garment business } \\
\text { from overseas that threaten my own } \\
\text { garment business (example China, } \\
\text { Vietnam and etc) }\end{array}$ & 2,136 & 0,192 & 1,576 \\
\hline & $\begin{array}{l}\text { c. products that are sold through } \\
\text { online market that threat my garment } \\
\text { business }\end{array}$ & 2,151 & 0,187 & 1,521 \\
\hline
\end{tabular}

TABLE 4: Description of Competitiveness Forces: The Strength of Supplier.

\begin{tabular}{|c|c|c|c|c|}
\hline No & Competitiveness & $\begin{array}{c}\text { Interval Scale } \\
\text { Strongly Strongly } \\
\text { Disagree Agree 1-5 }\end{array}$ & $\begin{array}{l}\text { Std.Error of } \\
\text { Mean }\end{array}$ & $\begin{array}{l}\text { Std. } \\
\text { Deviation }\end{array}$ \\
\hline \multirow[t]{2}{*}{ II } & $\begin{array}{l}\text { The Strength of Supplier } \\
\text { A. I need to maintain good } \\
\text { relationship between those who } \\
\text { provide raw materials for the } \\
\text { garment industry }\end{array}$ & $\begin{array}{l}4,098 \\
4,378\end{array}$ & $\begin{array}{l}0,139 \\
0,150\end{array}$ & $\begin{array}{l}\mathbf{1 , 1 3 4} \\
1,224\end{array}$ \\
\hline & $\begin{array}{l}\text { b. I can easily cut and change the } \\
\text { supplier of the raw material. }\end{array}$ & 3,818 & 1,189 & 1,538 \\
\hline
\end{tabular}

occur, the business owners may cut and change the supplier who previously provide them with raw materials. It is occurred because the business owners want to improve the quality of their product or when other supplier provides cheaper price for the same item.

The garment industry business owners agree that buyer as strength in controlling the business transaction in the market. However, only some of them who belive that they cannot meet the buyer's demand. It happens because the business owners has previously conduct market research before making their own product, so they are familiar with the buyer's demand and preference. The time when they cant meet the buyer's demand, the business owners will try to note it for their next production process.

The presence of wide range of option on the market makes the business owners in Agam region quite confidence with their own product. They believe that their products 
TABLE 5: Description of Competitiveness Forces: The Strenght of Bargaining among Buyer.

\begin{tabular}{|c|c|c|c|c|}
\hline No & Competitiveness & $\begin{array}{c}\text { Interval Scale } \\
\text { Strongly Strongly } \\
\text { Disagree Agree 1-5 }\end{array}$ & $\begin{array}{c}\text { Std.Error of } \\
\text { Mean }\end{array}$ & $\begin{array}{c}\text { Std. } \\
\text { Deviation }\end{array}$ \\
\hline III & $\begin{array}{l}\text { The Strength of Bargaining among } \\
\text { Buyer. } \\
\text { a. Buyer has power in controlling the } \\
\text { business transaction toward the } \\
\text { garment product at the market. }\end{array}$ & $\begin{array}{l}3,128 \\
3,348\end{array}$ & $\begin{array}{l}\mathbf{0 . 1 4 1} \\
0,209\end{array}$ & $\begin{array}{l}\mathbf{1 , 1 5 1} \\
\mathbf{1 , 7 0 5}\end{array}$ \\
\hline & b. I cannot meet the buyer's demand & 2,901 & 0,223 & 1,812 \\
\hline
\end{tabular}

TABLE 6: Description of Competitiveness Forces: Substitution Product.

\begin{tabular}{l|c|c|c|}
\hline No & $\begin{array}{c}\text { Interval Scale } \\
\text { Strongly Strongly } \\
\text { Disagree Agree 1-5 }\end{array}$ & $\begin{array}{c}\text { Std.Error of } \\
\text { Mean }\end{array}$ & $\begin{array}{c}\text { Std. } \\
\text { Deviation }\end{array}$ \\
\hline IV $\quad$ & $\mathbf{4 , 0 3 0}$ & $\mathbf{0 , 1 2 8}$ & $\mathbf{1 , 0 4 1}$ \\
\hline $\begin{array}{l}\text { Substitution Product } \\
\text { a. There is akin product on the } \\
\text { market }\end{array}$ & 3,439 & 0,216 & 1,755 \\
\hline $\begin{array}{l}\text { b. The product quality are equal to } \\
\text { other product }\end{array}$ & 4,621 & 0,100 & 0,818 \\
\hline Source: Primary Data & & & \\
\hline
\end{tabular}

are equal in term of quality with other products that are produced locally, regionally, and even from abroad.

TABLE 7: Description of Competitiveness Forces: Industrial Rivalry.

\begin{tabular}{|c|c|c|c|c|}
\hline No & Competitiveness & $\begin{array}{c}\text { Interval Scale } \\
\text { Strongly Strongly } \\
\text { Disagree Agree 1-5 }\end{array}$ & $\begin{array}{l}\text { Std.Error of } \\
\text { Mean }\end{array}$ & $\begin{array}{l}\text { Std. } \\
\text { Deviation }\end{array}$ \\
\hline \multirow[t]{2}{*}{ V } & $\begin{array}{l}\text { Industrial Rivalry } \\
\text { a. The competition in industry } \\
\text { encourage me to create high quality } \\
\text { product. }\end{array}$ & $\begin{array}{l}4,712 \\
4,909\end{array}$ & $\begin{array}{l}0,072 \\
0,041\end{array}$ & $\begin{array}{l}0,588 \\
0,338\end{array}$ \\
\hline & $\begin{array}{l}\text { b.There is fair competition among } \\
\text { business owners. }\end{array}$ & 4,515 & 0.133 & 1,084 \\
\hline
\end{tabular}

As they business owner focus on garment industry, they have to regularly create innovation on their products as well as to improve their quality in order to increase the number of their buyers. Improvement in innovation will also lead to fair competition in garment business market. 


\section{Conclusions}

Apparel industry is an ancestral type of business exist in KabupatenAgam for years. It was major economic locomotive for local people by the years of 2000. Since the rapid change of industrial environment in aspect of trade system, e-commerce, rivalry and local autonomy the apparel industry in Kabupaten is facing a slowdown number of its productivity. The major causes are lack of labor supply, entrants of new competitors, the strength beginning among buyer and in some part due to product substitution.

\section{Acknowledgements}

We would like to thank to the Government Republic of Indonesia represented by Kemenristek Dikti for funding the research project of Penelitian Kerjasama Perguruan Tinggi (PKPT) research scheme. Our gratitude to institutional support both come from STIE H.Agus Salim Bukittinggi and STIE EI Hakim Solok, colleagues, local government of KabupatenAgam, enumerators and the respondents for supplying necessary data and informations.

\section{References}

[1] Eka Budianti, Iwan Setiawan, Rafika Sari, Suhartono, Venti Eka Satya, The Prospect of Textile Industry and Textile Product toward Clothing Dignity, Pusat Penelitian Badan Keahlian Dewan Perwakilan Rakyat RI, Jakarta, 2016

[2] Agung Riyadi, Bambang Setiaji, Maulidiyah Indra Hasmarini, Triyono, Eni Setyowati, Growth Analysis of Textile Industry and Textile Product in several Provinces of Jawa Island, University Research Colloqium 2015, ISSN 2407-9189

[3] Agam in Figure, Central Statistics Bureau, 2016

[4] Yolamalinda, Analysis of Local Economic Potency in Developing Superior Commodity of Kabupaten Agam, Economica, Journal of Economic and Economic Education, Vol 3.No.1, 2014

[5] Juyoung Lee, Competitiveness of textile and apparel industries in the United States and Japan, htps://lib.dr.iastate.edu/cgi/viewcontent.cgi?article $=4524 \&$ context=etd

[6] Chavalit Nimlaor, Jirasek Trimetsoontorn and Wanno Fongsuwan, AEC (garment Industry Competitiveness, A Structural Equation Model of Thailand Role, Research of Journal Business Management, 9(1): 25-46, 2015 
[7] Wanshan Cheng, The Competitiveness of Export-Oriented Garment Industry in Guangdong (China) in the Post-Crisis Era, Lund University, https://lup.lub.lu.se/luur/ download?func=downloadFile \&recordOld=1917459\&fileOld=1939658

[8] Fitsum Hagos, Ajit Pal Singh, Rajwinder Singh, Determinants of Competitiveness ofGarment Industry in Ethiopia-An Empirical Study, Vol 22,Issue2, 2018 http:// journals.sagepub.com/doi/abs/10.1177/0972262918767042?journalCode=visa

[9] Erol Taymaz, Competitiveness of the Turkish Textile and Clothing Industries, September 15, 200, file:///C:/Users/Hp/Downloads/ Competitiveness_of_the_Turkish_Textile_and_Clothin.pdf

[10] Michael E. Porter, "How Competitive Forces Shape Strategy," May 1979 (Vol. 59, No. 2), pp. $137-145$ 